\title{
Paddy Loss and Its Implication to Fertilizer Subsidy in Indonesia
}

\author{
A Faroby Falatehan ${ }^{1 *}$, Yusman Syaukat ${ }^{1}$, Hastuti $^{1}$, Nizar Nasrullah $^{2}$ \\ ${ }^{1}$ Department of Resource and Environmental Economics, Faculty of Economics and Management, IPB University, Bogor, Indonesia \\ ${ }^{2}$ Department of Lanscape Architecture, Faculty of Agriculture, IPB University, Bogor, Indonesia
}

\section{ARTICLE INFO}

Article history:

Received October 21, 2019

Received in revised form October 16, 2020

Accepted October 20, 2020

\section{KEYWORDS:}

paddy postharvest technologies, fertilizer subsidy,

paddy and rice postharvest losses

\begin{abstract}
Indonesia is the third largest rice producer in the world, at the same time it's a country that imports rice from various countries. The government has provided input subsidies to increase rice production and reduce imports. Modes of rice farming in Indonesia is relatively diverse, from conventional to modern, even in the post-harvest process. The objectives of this study are: to analyze the impact of post-harvest handling on food loss and to analyze the relationship between paddy or rice loss with the quantity and value of fertilizers subsidy and paddy production in Indonesia. The estimated food (rice) loss includes the stages of harvesting, threshing, drying, and milling stages and distribution. Farmers use various technologies in processing rice: serrated sickle in harvesting, power thresher in threshing, and flatbed dryer in drying; while rice milling was done using conventional rice miller. The total rice loss reached 6.91 million tons in 2014 and continued to increase to 8.14 million tons in 2018. The growth rate of fertilizer subsidy value is higher than those of subsidized fertilizer quantity and paddy or rice loss. The results indicated that growth rates of paddy production and rice loss was lower than increased of government subsidy for fertilizer.
\end{abstract}

\section{Introduction}

Food and Agriculture Organization (2014) has strongly promoted a movement to support an increase in food availability apart from increasing production, namely by reducing the amount of food loss along the production and distribution chain (food loss) and decreasing food loss in consumption chain (food waste). Low production rate does not always become the main reason for inability to supply food. This could be due to high rate of food loss. According to FAO (2011), quantity of global food loss reached 33.3\% or equals 1.3 trillion ton per year.

Paddy harvesting area in Indonesia continued to increase from 13.80 million ha in 2014 to 16 million ha in 2018 (BPS 2020). In average, annual growth rate of harvesting area is about $3.79 \%$ in this period (Figure 1). Rice production is also increasing in the same period. Rice production increases from 70.85 million ton of milled dry paddy (MDP) in 2014 to 83.04 million tons in 2018. Thus, annual growth of rice production increase reached $4.07 \%$, higher than the

\footnotetext{
* Corresponding Author

E-mail Address: alfaroby@apps.ipb.ac.id
}

growth of area increase. Relatively higher production rate $(4.07 \%)$ compared to the area of harvesting rate $(3.79 \%)$ indicating that productivity of rice is slightly increasing $(0.28 \%)$ during the same period.

Paddy loss is one of the most important problems, particularly in Asia. Paddy loss may occur during the stages of production and distribution, normally including postharvest loss, and food wasted at consumption level, either at household level or certain institutions like hotel, hospital, and other institutions. Postharvest loss can occur in various chains, including harvesting, threshing, drying, storage, and transportation (ADM Institute for the Prevention of Postharvest Loss 2012). Postharvest loss is a complex problem and its scale varies for different crops, practices, climatic conditions, and country economic (Kumar and Kalita 2017). Iswari (2012) reported that paddy loss during harvesting in Indonesia is considered high, amounted to $9.52 \%$.

FAO (2011) reported that high food loss in developing country is also caused by low availability of adequate production technology in addition to lessqualified human resources to adapt to the available technology. Hence, traditional farmers still prefer to apply the conventional concept of farming despite the 


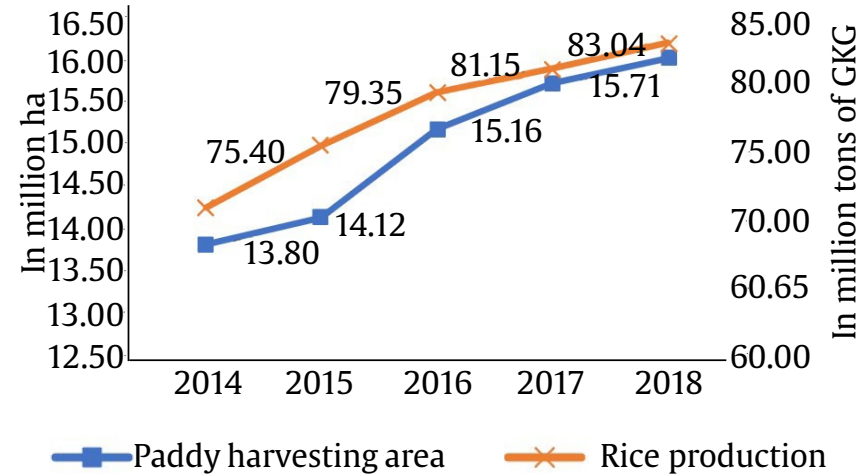

Figure 1. The development of rice area and rice production in Indonesia (GKG (Gabah Kering Giling) is MDP (Milled Dry Paddy) Source: BPS 2020)

availability of newer technology. Figure 2 provides a scheme illustrating the definition of food loss for rice commodity.

FAO (2014) has strongly promoted a movement to support an increase in food availability apart from increasing production, namely by reducing the amount of food loss along the production and distribution chain (food loss) and decreasing food loss in consumption chain (food waste). Apart from the classic problem commonly found in national rice, harvest and postharvest handlings significantly contribute to secure the production of national rice. In Indonesia, harvest and postharvest loss due to imperfect postharvest handling reached $20.51 \%$, consisted of loss during harvesting of $9.52 \%$, threshing of $4.78 \%$, drying of $2.13 \%$, and milling of $2.19 \%$. When the number is converted towards the national rice production of 54.34 million tons, yield loss will be higher than Rp 15 trillion (Purwanto 2005). Rutten and Verma (2014) stated that there is a modest increase in GDP $(0.8 \%)$ in Ghana when food loss is reduced by $50 \%$, and the welfare gains are equivalent of USD 19 per capita in 2025, increasing to USD 32 per capita per year by the year 2050, despite increasing population.

The first objective of this study is to estimate the quantity of paddy and rice loss during postharvest processes, including the process of transporting the product from farmer to processing. The loss of rice during post-harvest is quite high, reaching $20.5 \%$ in four stages, including: harvesting, threshing, drying, and grinding. In this study, food loss analysis considers the technology used by farmers in each process (Purwanto 2005).

Government of Indonesia provides fertilizer subsidies. Total expenses for fertilizer subsidy increase from Rp 17.9 trillion in 2014 to Rp 20.4 trillion in 2018. However, the government has not provided much stimulation to improve paddy farming technology to reduce paddy loss. Lipinski et al. (2013) stated that food loss have many negative economic and environmental impacts. From economic aspect, they represent a wasted investment that can reduce farmers' incomes and increase consumers' expenses. From environmental perspective, food loss inflicts a host of impacts, including unnecessary greenhouse gas emissions and inefficiently used water and land, which in turn can lead to diminish natural ecosystems and the services they provide. Thus, the second objective is to analyze the relationship between paddy/ rice losses with the quantity and value of fertilizer subsidy, and paddy production. Reducing food losses offers an important way of increasing food availability without requiring additional production resources, it can contribute to rural development and poverty reduction by improving agribusiness livelihoods (Hodges et al. 2011).

\section{Materials and Methods}

This study uses secondary data from Badan Pusat Statistik (Statistic Indonesia) from 2014 to 2018. The data includes rice production (in term of milled dry paddy or MDP), total population of Indonesia. The other secondary data are the quantity and value of fertilizer subsidy provided by the government. To estimate the value of food loss for paddy and rice in Indonesia are described in the below formulas.

\subsection{Estimation of Paddy Loss in Harvesting}

Estimation of paddy loss in harvesting was calculated using the following formula:

$$
\mathrm{PL}_{\mathrm{H}}=\mathrm{PH} \cdot \mathrm{CF}_{\mathrm{H}}
$$

Where $\mathrm{PL}_{\mathrm{H}}$ is estimate of the volume of paddy loss in harvesting, $\mathrm{PH}$ is paddy (MDP) production and $\mathrm{CFH}$ is conversion factor in paddy harvesting process. The conversion factor for harvesting is obtained from Purwanto (2005). Net paddy available after harvesting process (NPAH) is a difference between paddy production $(\mathrm{PH})$ and the estimate paddy loss in harvesting process $\left(\mathrm{PL}_{\mathrm{H}}\right)$. The NPAH equation is presented in equation (2).

$$
\mathrm{NPA}_{\mathrm{H}}=\mathrm{PH}-\mathrm{PL}_{\mathrm{H}}
$$




\section{Total Production Of Milled Dry Paddy}

$\nabla$

Not Edible

Edible

$\nabla$

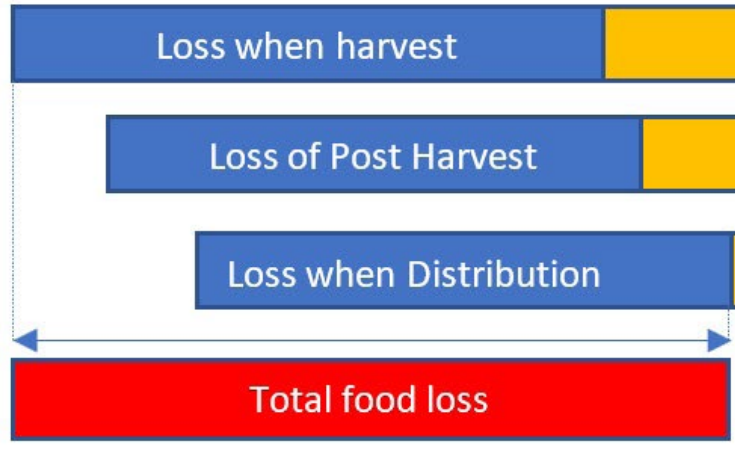

Available when harvest

Available after Post Harvest

$\nabla$

Figure 2. Definition of food loss of rice commodity according to FAO (2011)

\subsection{Estimation of Paddy Loss in Threshing}

Since threshing process comes after harvesting process, the estimation of paddy loss in threshing process $\left(\mathrm{PL}_{\mathrm{T}}\right)$ was calculated using the following formula:

$$
\mathrm{PL}_{\mathrm{T}}=\mathrm{NPA}_{\mathrm{H}} \cdot \mathrm{CF}_{\mathrm{T}}
$$

The $\mathrm{PL}_{\mathrm{T}}$ is a multiplication between the net amount of paddy available from the previous stage (i.e., from harvesting process NPAH) multiplied by the conversion factor (shrinkage of paddy wight) in threshing process $\left(\mathrm{CF}_{\mathrm{T}}\right)$. Due to this loss in threshing process, the net amount of paddy available after the threshing process is defined in equation (4).

$$
\mathrm{NPA}_{\mathrm{T}}=\mathrm{NPA}_{\mathrm{H}}-\mathrm{PL}_{\mathrm{T}}
$$

\subsection{Estimation of Paddy Loss in Drying}

Drying is the step of paddy processing stage after threshing. Similar to the above, the amount of paddy loss in drying process is presented in equation (5).

$$
\mathrm{PL}_{\mathrm{D}}=\mathrm{NPA}_{\mathrm{T}} \cdot \mathrm{CF}_{\mathrm{D}}
$$

Where $P L_{D}$ represents the amount of paddy loss in drying process, and $\mathrm{CF}_{\mathrm{T}}$ represents conversion rate (shrinkage of paddy weight) in drying process. The end result of drying process is the net amount of paddy available after drying process (NPAD). NPAD is presented in equation (6). It is the difference between NPAT and PLD.

$$
N P A_{D}=N P A_{T}-P L_{D}
$$

\subsection{Estimation of Paddy Loss in Milling}

Paddy milling is the next stage of paddy postharvest processes. The amount of paddy loss during the milling process $\left(\mathrm{PL}_{\mathrm{M}}\right)$ can be calculated using a formula in equation (7).

$$
\mathrm{PL}_{\mathrm{M}}=\mathrm{NPA}_{\mathrm{D}}-\mathrm{CF}_{\mathrm{M}}
$$

Where $\mathrm{NPA}_{\mathrm{D}}$ is net amount of paddy available after drying process, and $\mathrm{CF}_{\mathrm{M}}$ is conversion factor (shrinkage of paddy weight) in milling process. Net amount of paddy available after milling process $\left(\mathrm{NPA}_{\mathrm{M}}\right)$ is the final result of the rice milling process. $\mathrm{NPA}_{\mathrm{M}}$ formula is presented in equation (8).

$$
\mathrm{NPA}_{\mathrm{M}}=\mathrm{NPA}_{\mathrm{D}}-\mathrm{PL}_{\mathrm{M}}
$$

\subsection{Estimation of Loss in Distribution}

Distribution is the last postharvest process to estimate food (paddy) loss; and it comes after milling process. Calculation of paddy loss in distribution procession was done using the following formula, with correction factor in accordance with Bulog's research in Sulardjo (2014). 


$$
\mathrm{PL}_{\mathrm{Dis}}=\mathrm{NPA}_{\mathrm{M}} \cdot \mathrm{CF}_{\mathrm{Dis}}
$$

Where $\mathrm{PL}_{\mathrm{Dis}}$ is paddy loss in distribution process, $\mathrm{NPA}_{\mathrm{M}}$ is net paddy available after milling process, and $\mathrm{CF}_{\mathrm{Dis}}$ is conversion factor for paddy (shrinkage of paddy weight) in distribution process. The last estimate to the net amount of paddy available after distribution process is $\mathrm{NPA}_{\mathrm{Dis}}$ :

$$
\mathrm{NPA}_{\text {Dis }}=\mathrm{NPA}_{\mathrm{M}}-\mathrm{PL}_{\mathrm{Dis}}
$$

Data of correction factor of paddy losses in harvesting, threshing, drying, and milling processes are taken from Iswari (2012). The values of the conversion factors will be described in the results.

\section{Results}

\subsection{Estimated Paddy Postharvest Losses}

This study analyzes the amount of paddy losses when the postharvest systems applied the technology packages. Postharvest technology applied by farmers included the use of serrated sickle in harvesting (shrinkage rate of 7.8\%), power thresher in threshing (shrinkage rate of $1.9 \%$ ), sun drying in open field (shrinkage rate of $2.98 \%$ ), conventional milling machine (shrinkage rate of 2.19\%), and distribution (based on the assumption of Bulog of 1.61\%). Moreover, the percentage of conversion of MDP into rice used was $62.74 \%$.

\subsubsection{Harvesting}

During harvesting, loss is included in a series of broad and complex problems that are not only determined by technical problem, but also social and economic problem. Proper management will suppress high paddy loss in Indonesia. Table 1 explains total production of milled dry paddy (MDP), MDP loss during harvesting process, and net MDP available for the next process. By assuming a correction factor of shrinkage during harvesting is $7.80 \%$, total amount of MDP losses during the harvesting process are relatively large, ranging from 5.53 million tons of MDP in 2014 to 6.48 million tons of MDP in 2018. With these amounts of MDP losses, the net amount of MDP at the harvested stage $\left(\mathrm{NPA}_{\mathrm{H}}\right)$ presented in column (4), ranging from 65.32 million tons in 2014 to 76.56 million tons in 2018. These amount of MDPs are available to further stage i.e., threshing process.

The (3) column represents the equivalent rice loss in the harvesting stage i.e., multiplication of column
(2) and the correction factors of MDP converted into rice (62.74\%). When these losses are divided by the total population of Indonesia, they represent quite large amount of per capita rice losses due to the harvested losses: about $15.33 \mathrm{~kg} /$ capita/year or equivalent to $42.01 / \mathrm{gr} /$ capita/day in 2018 (Table 2 ).

\subsubsection{Threshing}

Threshing is the next processing stage for paddy after harvested. In this analysis, it is assumed that power thresher was used in threshing process since this tool is normally used by farmers in most regions in Indonesia. The conversion of MDP loss in threshing process using power thresher is $1.90 \%$. Net MDP after harvesting (column (4) of Table 1 ) becomes the basis for estimating the MDP and rice losses in threshing process. By applying the conversion rate of $1.90 \%$, the amount of MDP and rice in threshing process are presented in column (2) and (3) of Table 3. The MDP loss in threshing process varies 1.24 million ton in 2014 to 1.45 million ton in 2018. Net amount of MDP after threshing process (NPAT) is presented column (4) of Table 3.

If the amount of MDP in threshing process (column (3) of Table 3 ) is converted into rice loss, the amount of rice losses reaches 0.78 million ton in 2014 and 0.91 million ton in 2018. These figures are equivalent to $3.44 \mathrm{~kg} /$ capita/year of rice loss in 2018 due to threshing process only, or it's equivalent to $9.43 \mathrm{gram} /$ capita/day in 2018 (Table 4).

\subsubsection{Drying}

Drying is the next processing stage for paddy after threshing, thus net MDP after threshing becomes the basis for estimating the amount of MDP and rice in drying process. The correction factor of paddy shrinkage during drying process-using flatbed drier-is $2.98 \%$. With this conversion factor, the MDP and rice losses in drying process are presented in columns (2) and (3) of Table 5. The amount of MDP loss due to drying process vary from 1.91 million ton in 2014 and 2.24 million ton in 2018. With these amounts of MDP losses, the net amount of MDP after drying process (NPAD) is presented in column (4) of Table 5.

Rice loss due to drying process is presented in column (3) of Table 5, which vary from 1.20 million ton in 2014 and 1.40 million ton in 2018. The amount of rice loss per capita due to drying process vary from $4.75 \mathrm{~kg} /$ capita/year in 2014 and $5.30 \mathrm{~kg} /$ capita/year in 
2018. These are relatively large amount of individual rice losses per annum or per day (Table 6).

\subsubsection{Milling}

Net amount of MDP after drying process (column (4) of Table 5) becomes the basis in estimating MDP and rice losses in the next paddy processing stage i.e., milling process. If the conversion factor for the MDP loss in milling process is 2.19\%, the resulted MDP loss varies from 1.36 million ton in 2014 and 1.60 million ton in 2018 (column (2) of Table 7). Because of this MDP losses, the net amount of MDP after the milling process $\left(\mathrm{NPA}_{\mathrm{M}}\right)$ is presented in column (4) of Table 8 , which varies from 60.81 million ton in 2014 and 71.27 million ton in 2018.

Table 1. Estimated milled dry paddy (MDP) and rice losses in harvesting process in Indonesia, 2014-2018

\begin{tabular}{lcccc}
\hline Year & $\begin{array}{c}\text { Production of MDP } \\
\text { (million ton) }(1)\end{array}$ & $\begin{array}{c}\text { Total amount of MDP } \\
\text { loss (million ton) }(2)=(1)^{*} 7.80 \%\end{array}$ & $\begin{array}{c}\text { Amount of rice Loss } \\
\text { (million ton) } \\
(3)=(2)^{*} 62.74 \%\end{array}$ & $\begin{array}{c}\text { Net MDP after } \\
\text { harvesting (million } \\
\text { ton) }(4)=(1)-(2)\end{array}$ \\
\hline 2014 & 70.85 & 5.53 & 3.47 & 65.32 \\
2015 & 75.40 & 5.88 & 3.69 & 69.52 \\
2016 & 79.35 & 6.19 & 3.88 & 73.17 \\
2017 & 81.15 & 6.33 & 3.97 & 74.82 \\
2018 & 83.04 & 6.48 & 4.06 & 76.56 \\
\hline
\end{tabular}

Correction factor of shrinkage during harvesting is $7.80 \%$

Correction factor of MDP converted into rice is 62.74\%

Table 2. Estimated rice losses per capita due to harvest loss in Indonesia, 2014-2018

\begin{tabular}{ccccc}
\hline Year & $\begin{array}{c}\text { Amount of rice loss } \\
\text { (million ton) }\end{array}$ & Population (million people)* & $\begin{array}{c}\text { Rice loss per year } \\
\text { (Kg/cap/year) }\end{array}$ & $\begin{array}{c}\text { Rice loss per day } \\
\text { (g/cap/day) }\end{array}$ \\
\hline 2014 & 3.47 & 252.16 & 13.75 & 37.67 \\
2015 & 3.69 & 255.46 & 14.44 & 39.57 \\
2016 & 3.88 & 258.71 & 15.01 & 41.13 \\
2017 & 3.97 & 261.89 & 15.16 & 41.54 \\
2018 & 4.06 & 265.02 & 15.33 & 42.01 \\
\hline
\end{tabular}

${ }^{*}$ Source: BPS 2020

Table 3. Estimated milled dry paddy (MPD) and rice losses in threshing process in Indonesia, 2014-2018

\begin{tabular}{ccccc}
\hline Year & $\begin{array}{c}\text { Net MDP after harvesting } \\
\text { (million ton)(1) }\end{array}$ & $\begin{array}{c}\text { MDP loss in threshing } \\
\text { (million ton) } \\
(2)=(1)^{*} 1.90 \%\end{array}$ & $\begin{array}{c}\text { Rice loss in threshing } \\
\text { (million ton) } \\
(3)=(2)^{*} 62.74 \%\end{array}$ & $\begin{array}{c}\text { Net MDP after threshing } \\
\text { (million ton) } \\
(4)=(1)-(2)\end{array}$ \\
\hline 2014 & 65.32 & 1.24 & 0.78 & 64.08 \\
2015 & 69.52 & 1.32 & 0.83 & 68.20 \\
2016 & 73.17 & 1.39 & 0.87 & 71.77 \\
2017 & 74.82 & 1.42 & 0.89 & 73.40 \\
2018 & 76.56 & 1.45 & 0.91 & 75.11 \\
\hline
\end{tabular}

Correction factor of shrinkage during threshing is $1.90 \%$

Correction factor of MDP converted into rice is $62.74 \%$

Table 4. Estimated rice loss per capita due to threshing process in Indonesia, 2014-2018

\begin{tabular}{ccccc}
\hline Year & $\begin{array}{c}\text { Amount of rice } \\
\text { loss (million ton) }\end{array}$ & $\begin{array}{c}\text { Population } \\
\text { (million people) }\end{array}$ & $\begin{array}{c}\text { Rice loss per year } \\
\text { (kg/cap/year) }\end{array}$ & $\begin{array}{c}\text { Rice loss per day } \\
\text { (g/cap/day) }\end{array}$ \\
\hline 2014 & 0.78 & 252.16 & 3.09 & 8.46 \\
2015 & 0.83 & 255.46 & 3.24 & 8.89 \\
2016 & 0.87 & 258.71 & 3.37 & 9.24 \\
2017 & 0.89 & 261.89 & 3.41 & 9.33 \\
2018 & 0.91 & 265.02 & 3.44 & 9.43 \\
\hline
\end{tabular}

*Source: BPS 2020 
Table 5. Estimated milled dry paddy (MDP) and rice losses in drying process in Indonesia, 2014-2018

\begin{tabular}{ccccc}
\hline Year & $\begin{array}{c}\text { Net MDP after threshing } \\
\text { (million ton) } \\
(1)\end{array}$ & $\begin{array}{c}\text { MDP loss in drying } \\
\text { process (million ton }) \\
(2)=(1)^{*} 2.89 \%\end{array}$ & $\begin{array}{c}\text { Rice loss in drying process } \\
\text { (million ton) } \\
(3)=(2) * 62.74 \%\end{array}$ & $\begin{array}{c}\text { Net MDP after drying } \\
(\text { million ton })\end{array}$ \\
\hline 2014 & 64.08 & 1.91 & 1.20 & 62.17 \\
2015 & 68.20 & 2.03 & 1.28 & 66.16 \\
2016 & 71.77 & 2.14 & 1.34 & 69.64 \\
2017 & 73.40 & 2.19 & 1.37 & 71.21 \\
2018 & 75.11 & 2.24 & 1.40 & 72.87 \\
\hline
\end{tabular}

Correction factor of shrinkage during drying is $2.98 \%$

Correction factor of MDP converted into rice is $62.74 \%$

Table 6. Estimated rice loss per capita due to drying process in Indonesia, 2014-2018

\begin{tabular}{cccccc}
\hline Year & $\begin{array}{c}\text { Amount of rice loss } \\
\text { (million ton) }\end{array}$ & $\begin{array}{c}\text { Amount of MDP } \\
\text { during drying }\end{array}$ & $\begin{array}{c}\text { Population } \\
\text { (million people) }\end{array}$ & $\begin{array}{c}\text { Rice loss per year } \\
\text { (kg/cap/year) }\end{array}$ & $\begin{array}{c}\text { Rice loss per day } \\
\text { (g/cap/year) }\end{array}$ \\
\hline 2014 & 1.20 & 62.17 & 252.16 & 4.75 & 13.02 \\
2015 & 1.28 & 66.16 & 255.46 & 4.99 & 13.67 \\
2016 & 1.34 & 69.64 & 258.71 & 5.19 & 14.21 \\
2017 & 1.37 & 71.21 & 261.89 & 5.24 & 14.36 \\
2018 & 1.40 & 72.87 & 265.02 & 5.30 & 14.52 \\
\hline
\end{tabular}

*Source: BPS 2020

Table 7. Estimated milled dry paddy (MDP) and rice losses in milling process in Indonesia, 2014-2018

\begin{tabular}{lcccc}
\hline Year & $\begin{array}{c}\text { Net MDP after drying } \\
\text { (million ton) }(1)\end{array}$ & $\begin{array}{c}\text { MDP loss in drying } \\
\text { process (million ton }) \\
(2)=(1)^{*} 2.19 \%\end{array}$ & $\begin{array}{c}\text { Rice loss in drying } \\
\text { process (million ton }) \\
(3)=(2)^{*} 62.74 \%\end{array}$ & $\begin{array}{c}\text { Net MDP after milling } \\
\text { process (million ton) } \\
(4)=(1)-(2)\end{array}$ \\
\hline 2014 & 62.17 & 1.36 & 0.85 & 60.81 \\
2015 & 66.16 & 1.45 & 0.91 & 64.71 \\
2016 & 69.64 & 1.53 & 0.96 & 68.11 \\
2017 & 71.21 & 1.56 & 1.00 & 69.65 \\
2018 & 72.87 & 1.60 & 71.27 \\
\hline
\end{tabular}

Correction factor of shrinkage during milling is $2.19 \%$

Correction factor of MDP converted into rice is $62.74 \%$

Table 8. Estimated rice loss per capita due to milling process in Indonesia, 2014-2018

\begin{tabular}{ccccc}
\hline Year & $\begin{array}{c}\text { Rice loss in milling } \\
\text { process (million ton) }\end{array}$ & $\begin{array}{c}\text { Population } \\
\text { (million people) }\end{array}$ & $\begin{array}{c}\text { Rice loss per year } \\
\text { (kg/cap/year) }\end{array}$ & $\begin{array}{c}\text { Rice loss per day } \\
\text { (g/cap/year) }\end{array}$ \\
\hline 2014 & 0.85 & 252.16 & 3.39 & 9.28 \\
2015 & 0.91 & 255.46 & 3.56 & 9.75 \\
2016 & 0.96 & 258.71 & 3.70 & 10.13 \\
2017 & 0.98 & 261.89 & 3.74 & 10.24 \\
2018 & 1.00 & 265.02 & 3.78 & 10.35 \\
\hline
\end{tabular}

*Source: BPS 2020

\subsubsection{Distribution}

Distribution process is the next stage of paddy process after the milling process. It is the last step in estimated the rice postharvest loss. Net MDP after milling process is the basis data in estimating the rice loss in the distribution process. The conversion factor for distribution process is assumed to be $1.61 \%$. With this conversion factor, the amount of MDP and rice loss during the distribution process are presented in columns (2) and (3) of Table 9. The amount of MDP loss in distribution process $\left(\mathrm{PL}_{\mathrm{D}}\right)$ was 0.98 million tons in 2014 and further increased to 1.21 million tons in 2018. Column (4) of Table 9 represents the total amount of MDP available after distribution process. These figures represent total amount of paddy available to the consumers at the distribution level. 
The amount of rice available at the last postharvest process should be converted by $62.74 \%$ as presented in column (5) of Table 9. These are the amount of rice available to be purchased by consumers.

The amount of rice loss in distribution process reaches 0.61 million tons in 2014 and 0.76 million tons in 2018 (column (3) of Table 9). Rice loss per capita due to distribution process in 2014 and 2018 (Table 10). The rice loss reached $2.44 \mathrm{~kg} /$ capita/year in 2014 and increased to $2.86 \mathrm{~kg} /$ capita/year in 2018 . These figures are equivalent to daily rice loss of 6.67 gram/capita/day in 2014 and 7.84 gram/capita/day in 2018.

\subsection{Government Fertilizer Subsidy Policy}

One of government policies made for the paddy farmers is fertilizer subsidy. This subsidy is given to farmers who own agricultural area of less than 2 ha. For the last 5 years, realization of fertilizer subsidy for farmer fluctuated, depended on the value of fertilizer absorbed. In the period of 2014 to 2018 , realization of fertilizer subsidy continues to increase over time, from Rp 17.9 trillion in 2014 to Rp 28.8 trillion in 2017.

Based on data on Figure 3, the time trend (exponential model) for the values of fertilizer subsidy, quantity of fertilizer subsidy, paddy production, and rice loss are $17.03 \%, 1.63 \%, 4.58 \%$, and $4.72 \%$ per annum, respectively, for the period of 2014 to 2017 . Growth rate of paddy production is $4.58 \%$ per annum, while the growth rate of rice loss is 4.72 percent per annum, indicating that the rate of rice loss is slightly higher than that of paddy production. Without improvement in post-harvest technology, rice loss tends to increase slightly higher than its production growth.

Growth rate of the quantity of fertilizer subsidy is greater than the rate of fertilizer subsidy value, $1.63 \%$ compared to $17.03 \%$. This indicating that the prices of subsidized fertilizers increase over time, its net increase is about $15.40 \%$ per annum. Similar comparison shows that the rate of rice loss (4.72\%) is also significantly higher than that of the quantity of subsidized fertilizer $(1.63 \%)$ and that of paddy production (4.58\%), which implies that increase in the quantity of subsidized fertilizer does not reduce the level of postharvest rice losses. Simple regression analysis with limited data also indicated that rice loss has positive relationship with paddy production, quantity of subsidized fertilizer, as well as value of fertilizer subsidy. These results were due to the method of government subsidy provided to the farmers, which was fixed at Rp 2,000 per $\mathrm{kg}$ and to stabilize price of fertilizer over time, though inflation of supporting activity in fertilizer subsidy such as labor cost and transportation cost continued to increase.

Table 9. Estimated MDP and rice losses in distribution process and total rice available for consumption in Indonesia, 20142018

\begin{tabular}{|c|c|c|c|c|c|}
\hline Year & $\begin{array}{l}\text { Net MDP after } \\
\text { milling process } \\
(\text { million ton })(1)\end{array}$ & $\begin{array}{l}\text { MDP loss in distribution } \\
\text { process (million ton) } \\
(2)=(1) * 1.61 \%\end{array}$ & $\begin{array}{l}\text { Rice loss in distribution } \\
\text { process (million ton) } \\
(3)=(2) * 62.74 \%\end{array}$ & $\begin{array}{c}\text { Net MDP after } \\
\text { distribution process } \\
\text { (million ton) } \\
(4)=(1)-(2)\end{array}$ & $\begin{array}{l}\text { Net rice available } \\
\text { for consumption } \\
\text { (million ton) } \\
(5)=(4) * 62.74 \%\end{array}$ \\
\hline 2014 & 60.81 & 0.98 & 0.61 & 59.83 & 37.54 \\
\hline 2015 & 68.20 & 1.10 & 0.69 & 67.10 & 42.10 \\
\hline 2016 & 71.77 & 1.16 & 0.73 & 70.62 & 44.31 \\
\hline 2017 & 73.40 & 1.18 & 0.74 & 72.22 & 45.31 \\
\hline 2018 & 75.11 & 1.21 & 0.76 & 73.90 & 46.36 \\
\hline
\end{tabular}

Correction factor of shrinkage during distribution is $1.61 \%$

Correction factor of MDP converted into rice is $62.74 \%$

Table 10. Estimated rice loss per capita due to distribution process in Indonesia, 2014-2018

\begin{tabular}{ccccc}
\hline Year & $\begin{array}{c}\text { Amount of rice loss } \\
\text { (million ton) }\end{array}$ & $\begin{array}{c}\text { Population } \\
(\text { million people) }\end{array}$ & $\begin{array}{c}\text { Rice loss Per year } \\
(\mathrm{kg} / \text { cap/year })\end{array}$ & $\begin{array}{c}\text { Rice loss per day } \\
(\mathrm{g} / \mathrm{cap} / \mathrm{year})\end{array}$ \\
\hline 2014 & 59.83 & 252.16 & 2.44 & 6.67 \\
2015 & 67.10 & 255.46 & 2.70 & 7.39 \\
2016 & 70.62 & 258.71 & 2.80 & 7.68 \\
2017 & 72.22 & 261.89 & 2.83 & 7.76 \\
2018 & 73.90 & 265.02 & 2.86 & 7.84 \\
\hline
\end{tabular}

*Source: BPS 2020 


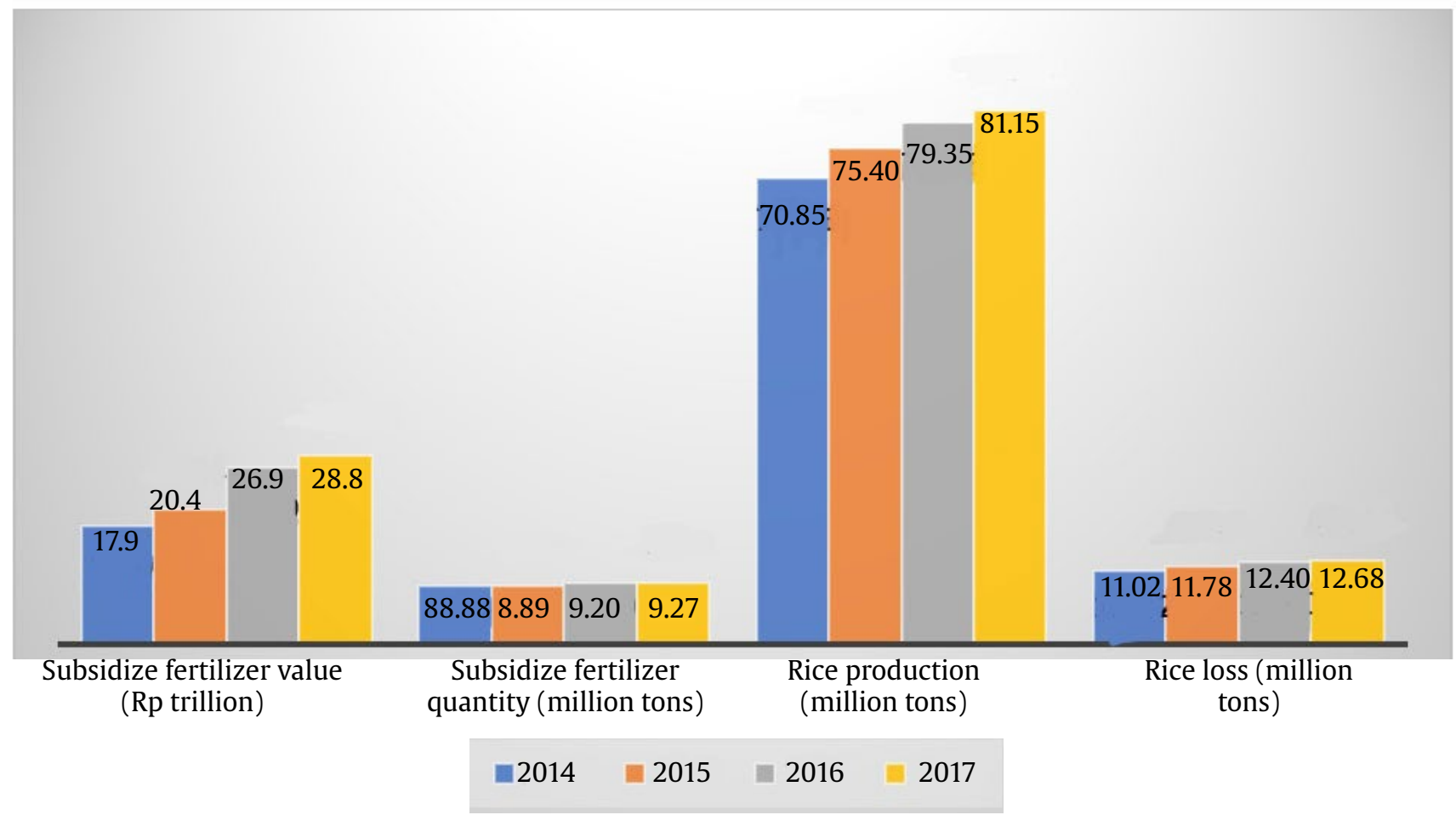

Figure 3. The value of fertilizer subsidy, total number fertilizer distribution, total rice production and total rice loss in Indonesia, 2014-2018

\section{Discussion}

There are some approaches to increase food availability, namely: i) increase production through area expansion; ii) increase productivity per unit area through intensification (defined here as increased amounts of inputs per unit area); iii) reduce food loss and wastage from the field to the fork; and iv) increase cropping intensity i.e., using the same land to produce more than one crop a year (Khader et al. 2019). Postharvest technology and the combination of the use of postharvest equipment highly affect yield loss. Iswari (2012) conducted inventory to assess the impact of postharvest technology applied on the paddy yield obtained related to the crop yield shrinkage.

The types of technologies applied in postharvest processes affect the amount of paddy/rice loss. Based on Table 11, the simple technology applied by farmers generated the highest shrinkage value, amounted to $21 \%$. The technology was really simple as they used sickle, performed paddy threshing manually or by applying manual threshing system, and conducted conventional drying and milling. The second highest shrinkage value of $19.33 \%$ was obtained by using postharvest technology that has applied mechanization, i.e. the use of pedal thresher in paddy threshing. Less shrinkage of $13 \%$ was found when applying advanced postharvest technology. Farmers used reaper in harvesting, power thresher in threshing, and flat-bed drier in drying. They also used modified milling. At the next level, more advanced mechanization technology was applied and resulted in only $6.6 \%$ of shrinkage. Hence, based on this illustration, better technology leads to lower shrinkage.

In this study, the package of technology to be applied by farmers included the use of serrated sickle in harvesting, power thresher in threshing, and flatbed dryer in drying. Milling was done using conventional rice miller, and distribution loss was estimated using the method established by Bulog. With these technology in paddy postharvest system, the total milled dry paddy (MDP) loss reached $16.3 \%$, which is equivalent to 11.02 million ton of MDP losses in 2014, and 12.97 million ton of MDP losses in 2018. In term of rice loss, it varies from 6.91 million ton in 2014 and 8.14 million ton in 2018. These figures represent significant large amount of paddy/rice losses in Indonesia. Post-harvest loss of paddy in other countries are lower than Indonesia. Post-harvest loss in Sri Lanka is $12 \%$, Thailand $14.6 \%$, Bangladesh 13.2\%, and Nepal 16\% (Khan 2010). 
Table 11. Various models of postharvest processing and its shrinkage value

\begin{tabular}{llr}
\hline Model & Activities & Shrinkage value (\%) \\
\hline A & Harvesting with traditional sickle & 2.19 \\
& Manual threshing with rack & 1.61 \\
& Drying in the floor & 21.09 \\
Conventional milling & 7.80 \\
Others & 4.75 \\
Shrinkage A & 2.98 \\
Harvesting with jagged sickle & 2.19 \\
Threshing with pedal thresher & 1.61 \\
& Drying in the floor & 19.33 \\
Conventional milling & 6.00 \\
Others & 1.90 \\
Shrinkage B & 2.30 \\
Harvest with reaper machine & 1.19 \\
Threshing with power thresher & 1.61 \\
& Drying in flat bed dryer & 13.00 \\
& Milling with modification I & 2.00 \\
Others & 1.90 \\
Shrinkage C & 2.30 \\
& Harvest with paddy mower & 0.19 \\
Threshing with power tresher & 1.61 \\
& Drying in flat bed dryer & 8.00 \\
& Milling with modification I & 2.50 \\
Others & 2.30 \\
Shrinkage D & 0.19 \\
& Harvest with combine harvester & 1.61 \\
& Drying in flat bed dryer & 6.60
\end{tabular}

Model A: Purwandaria et al. (1994); B, C, D: Thahjohutomo (2008); E: Mix

The growth rate of fertilizer subsidy value was found to be higher than those of fertilizer quantity and rice loss. The growth rate of rice loss paralleled with the increasing growth of rice production. Increase in fertilizer quantity have positive relationship with both rice production and rice loss. The data indicated that the growth fertilizer subsidy value is much greater of fertilizer quantity, paddy production, and paddy/rice loss, indicating that the fertilizer subsidy has not been effective in reducing paddy/rice loss.

Hence, government should consider the subsidy pattern since increase in fertilizer subsidy does not only increase the paddy production, but also increase the paddy/rice loss. This condition is similar to the results research of Begum et al. (2012), which stated that the postharvest paddy losses were positively and significantly conditioned by total production of rice. In macro level, the Bangladesh Agricultural Research Institute (BARI) showed that the total preventable post-harvest losses of food grains at 12-15 percent of the total production, which is equivalent to 4.15 to 5.19 million metric tons.
Government in many countries have implemented many policies to reduce food loss. In Indonesia, as in others countries, technology plays important role in affecting postharvest loss of paddy. On the other hand, increase in government subsidy has not been effective in reducing paddy/rice postharvest loss. Therefore, the government should find out alternative farmers' assistance program besides subsidy of fertilizer. In this case, the government should provide a specific program (policy) to improve postharvest technology adopted by the farmers, since better technologies to reduce postharvest loss are available, but have not implemented by the farmers. These could include the use of combined harvester, flat bed drier for drying, and technology in rice milling. The government should also facilitate the farmers to be able to adopt those technologies.

Considering that efforts to increase rice productivity are increasingly difficult, efforts to suppress or reduce the rate of paddy or rice loss must be prioritized in order to meet the increasing demands for food (rice). The agricultural production 
has the potential to be increased if the available lands can be utilized optimally (Syaukat et al. 2019). To meet this objective, Government of Indonesia should have a specific policy in reducing foodloss. Implementation of the types of technologies of rice postharvest systems have critical factors. Among the postharvest critical stages, harvesting, drying and distribution are especially important, because between $10-40 \%$ of the food that is grown never reaches the market or a consumer's plate (Saba and Ibrahim 2018).

An illustration of the integrated efforts to reduce of food loss can be seen in Canada. In 2016, the National Zero Waste Council prepared strategies to reduce food loss and waste in Canada. The strategy was built around three pillars: national, provincial and local policy changes; innovation in technology and community infrastructure; and behavior change throughout the supply chain. The actions under each pillar are combined to tackle food waste challenges, from post-farm to the consumer.

In Tanzania, post-harvest losses is estimated to be $30-40 \%$ for cereals and even higher for perishable crops. As a response to this situation, Ministry of Agriculture in Tanzania, in collaboration with other stakeholders developed the National Post-harvest Management Strategy (NPHMS). This institution implemented over a ten-year period and focused on certain food crops, particularly cereals, legumes, fruits and vegetables, roots and tubers and edible oil crops. The strategy intends to provide significant interventions that will reduce post-harvest losses and potentially offset this food deficit.

\section{Acknowledgements}

We gratefully thank the Directorate General of Research Enhancement and Development, Ministry of Research Technology and Higher Education and Bogor Agricultural University for the funding supports for this research.

\section{References}

ADM Institute for the Prevention of Postharvest Loss. 2012. Mapping the Production Systemand the Supply Chain and Study the Crop Losses of Black Gram. Illinois (IT): ADM Institute for the Prevention of Postharvest Loss.
Begum EA et al. 2012. Economic analysis of post-harvest losses in food grains for strengthening food security in Northern Regions of Bangladesh. IJAR-BAE 1:56-65.

BPS. 2020. Statistical Yearbook of Indonesia 2020. Jakarta: Badan Pusat Statistik.

[FAO] Food Agriculture Organization 2011. Global Food Losses and Food Waste-Extent, Causes and Prevention. Rome: FAO.

[FAO] Food Agriculture Organization 2014. Global Initiative of Food Losses and Waste Reduction. Roma: FAO.

Hodges RJ et al. 2011. Postharvest losses and waste in developed and less developed countries: opportunities to improve resource use. Journal of Agricultural Science 149:37-45.

Iswari K. 2012. Kesiapan teknologi panen dan pascapanen padi dalam menekan kehilangan hasil dan meningkatkan mutu beras. Jurnal Litbang Pertanian 31:58-67.

Khader BFY et al. 2019. Where in the value chain are we losing the most food? the case of wheat in Jordan. Food Security 11:1009-1027.

Khan MA. 2010. Post Harvest Losses of Rice. Trade Development Authority of Pakistan.

Kumar D, Kalita P. 2017. Reducing postharvest losses during storage of grain Crops to strengthen food security in developing countries. Foods 6:1-22.

Lipinski B et al. 2013. Reducing Food Loss and Waste. Installment 2 of "Creating a Sustainable Food Future". Working Paper. World Resource Institute.

Purwandaria HK et al. 1994. Development of stripping and threshing type harvester. Postharvest Technologies for Rice in the Humid Tropics. Philippines: Technical Report Submitted to GTZ-IRRI Project. IRRI.

Purwanto YA. 2005. Kehilangan Pasca Panen Padi Kita Masih Tinggi. Bogor: IPB.

Rutten M, Verma M, 2014. The Impacts of Reducing Food Loss in Ghana; A scenario study using the global economic simulation model MAGNET. Wageningen: LEI Wageningen UR.

Saba SS, Ibrahim HI. 2018. Postharvest loss in rice: causes, stages, estimates and policy implications. Agri Research and Technology: Open Access Journal 15:555964. DOI:10.19080/ARTOAJ.2018.15.555964

Sulardjo. 2014. Penanganan pascapanen padi. Magistra 26: 44-58

Syaukat Y et al. 2019. Drought Mitigation Strategy of Farmers in South of West Java. In: LoCARNet: The 7th Annual Meeting - Challenges for Asia to Meet $1.5^{\circ} \mathrm{C}$ Target. IOP Conf. Series: Earth and Environmental Science. pp. 1-6. DOI:10.1088/1755-1315/363/1/012017

Thahjohutomo R. 2008. Komersialisasi inovasi teknologi hasil penelitian dan pengembangan pertanian. Disampaikan pada workshop membangun sinergi A-B-G dalam komersialisasi hasil litbang alsintan lokal dalam negeri, FATETA IPB, Bogor, 6 Agustus 2008. Jakarta: Badan Penelitian dan Pengembangan Pertanian. 